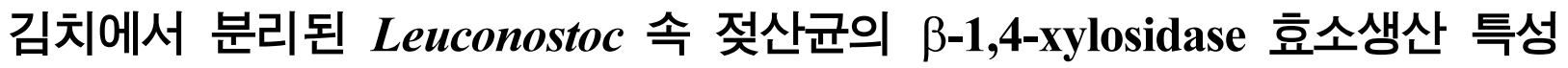

\author{
장미희 • 김명동* \\ 강원대학교 바이오산업공학부

\section{及-1,4-Xylosidase Activity of Leuconostoc Lactic Acid Bacteria Isolated from Kimchi}

\author{
Mi-Hee Jang and Myoung-Dong Kim* \\ School of Biotechnology and Bioengineering, Kangwon National University
}

\begin{abstract}
The $\beta$-xylosidase (EC 3.2.1.37) production capabilities of lactic acid bacteria in the genus Leuconostoc, isolated from a variety of kimchi (fermented vegetables), were examined. The intracellular levels of $\beta$-xylosidase were similar to the extracellular levels, when most Leuconostoc lactic acid bacteria were grown in a medium containing xylose as the carbon source. Intracellular $\beta$-xylosidase with a maximum activity of $1.2 \pm 0.1$ units $/ \mathrm{mL}$ (mean \pm standard error) was obtained from Leuconostoc lactis KCTC 13344, which was isolated from fermented Chinese cabbage. The optimum reaction conditions for Leu. lactis KCTC $13344 \beta$-xylosidase activity were $\mathrm{pH} 6.0$ and $30^{\circ} \mathrm{C}$, and the addition of most divalent cations, except zinc, to the reaction mixture resulted in a slight increase in enzyme activity. Compared with a media containing other carbon sources, the $\beta$-xylosidase activity was 5 times higher when Leu. lactis KCTC 13344 was grown in a medium containing xylose as carbon source. Zymographic analysis indicated that the synthesis of Leu. lactis KCTC $13344 \beta$-xylosidase (approximate size, $64 \mathrm{kDa}$ ) is induced by xylose. A maximum intracellular $\beta$-xylosidase activity of $7.1 \pm 0.3$ units $/ \mathrm{mL}$ was obtained in a batch cultivation in an MRS medium containing $30 \mathrm{~g} / \mathrm{L}$ xylose.
\end{abstract}

Keywords: $\beta$-xylosidase, kimchi, lactic acid bacteria, Leuconostoc lactis, xylose

\section{서 론}

인류는 수천 년 동안 발효식품 생산을 위하여 젖산균을 이용 하여 왔는데, 젖산균은 맛, 풍미 그리고 조직감에서 바람직한 변 화를 일으킬 뿐만 아니라 식중독 및 부패 미생물들의 생육을 억 제할 수 있는 발효능력을 가지고 있기 때문이다. 젖산균은 오랫 동안 산업적으로 이용되어 온 중요한 균주의 하나로, 우유 가공 품과 발효식품인 김치, 간장, 된장 등에서 매우 중요한 역할을 담 당하고 있다(1). 특히 프로바이오틱 젖산균은 장관의 미생물 균 총 유지, 유당 불내증의 완화, 혈중 콜레스테롤의 감소, 항암작 용, 면역 증강작용, 식품의 영양학적 가치 증진 등의 유익한 효 과와 변비의 완화, 유아의 설사 방지 등의 효능을 가지는 것으로 알려져 있다(2-4). 김치 및 발효 유제품으로부터 분리된 젖산균과 공시 젖산균주를 대상으로 내산성, 내담즙성, 장내 부착능, 병원 성균 억제능 등의 프로바이오틱 특성과 장관 면역활성 및 대식 세포 활성 등의 면역활성을 연구한 결과 Lactobacillus acidophilus 균주인 DDS-1과 B3208이 프로바이오틱 균주로서 요구되는 조건 을 충족시키는 것으로 보고되었다(5).

*Corresponding author: Myoung-Dong Kim, School of Biotechnology and Bioengineering, Kangwon National University, Chuncheon, Gangwon 200-701, Korea

Tel: $82-33-250-6458$

Fax: 82-33-241-0508

E-mail: mdkim@kangwon.ac.kr

Received October 8, 2010; revised January 13, 2011; accepted January 14, 2011
$\beta$-Xylosidase는 자연에서 셀룰로스 다음으로 많이 존재하는 탄 수화물인 자일란을 자일로스로 가수분해하기 위하여 endoxylanase, $\alpha$-arabinosidase와 함께 요구되는 효소이다(6). 또한 최종산물에 의 한 endoxylanase의 억제를 감소시키는데 기여하기 때문에 미생물 의 자일란 분해계에서 매우 중요한 효소 중의 하나이다(6). 자일 란은 최근 대체에너지인 바이오에탄올의 생산을 위한 기질로서 주목을 받고 있을 뿐만 아니라, 부탄올과 같은 유기용매 및 자일 리톨과 같은 감미료의 생산원료로서도 그 이용이 기대되고 있는 중요한 바이오매스 자원 중의 하나이다(7-9). 자일란과 같은 고분 자 물질을 효율적으로 이용하기 위해서는 자일로스와 같은 발효 가능한 기질로 전환하는 공정이 필요한데, 이와 같은 전환공정에 는 산 또는 알칼리에 의한 가수분해 공정과 효소에 의한 가수분 해 공정이 있다(10). 전자의 경우에는 반응속도가 빠르다는 장점 이 있으나 전처리 과정에서 섬유소의 분해산물과 함께 생성되는 각종 유해물질이 미생물의 발효를 저해할 수 있으나(10), 효소를 이용한 전처리 공정은 상온 - 상압의 조건에서 운전이 가능하고 미생물의 발효 작용을 억제하는 저해물질이 생성되지 않는 등의 장점이 있기 때문에 화학적 당화공정보다 미생물이 보유하고 있 는 효소에 의한 가수분해 공정이 보다 유리하다(10). 대기 중으 로 배출되는 이산화탄소 배기가스를 저감하기 위한 방법의 하나 로서 바이오에탄올은 발효를 통해 바이오매스로부터 생산되어 자 동차 연료로 사용되고 있으며, 사용되는 균주는 대부분 재조합 Saccharomyces cerevisiae 또는 Escherichia coli로서 이들은 자일 로스를 바이오에탄올로 전환시키는 능력이 대사공학적으로 부여 된 것이다(11-14). 젖산균을 이용하여 자일로오스를 발효할 경우 에 생성되는 젖산은 생분해성 플라스틱을 제조하는 원료로 이용 
될 수 있다(15). 따라서 효율적으로 자일로오스를 탄소원으로 이 용하는 젖산균을 확보한다면 바이오매스를 더욱 효율적으로 이 용할 수 있는 기술적 기반을 구축하는데 기여할 것으로 기대된 다(15).

세균과 효모에서 생산되는 $\beta$-xylosidase는 주로 세포내에 존재 하며(16), 곰팡이에서는 배양액과 세포 표면에서 발견되는 것으 로 알려져 있다(17). $\beta$-Xylosidase의 생합성 조절기작에 관한 연 구는 일부 곰팡이에 대하여 보고되었고(18), 특히 Aspergillus, Penicillium 및 Trichoderma 속에 의해 생산되는 $\beta$-xylosidase에 대 한 연구결과가 많이 보고되었는데, 이들 곰팡이 유래의 효소들은 여러 크기의 단일 폴리펩타이드로 구성되어 있고(17-19), 세균의 경우는 Bacillus와 Clostridium 속 균주에서 생산되는 $\beta$-xylosidase 가 주로 연구되었는데, 곰팡이 유래의 $\beta$-xylosidase에 비해 분자 량, 최적 반응온도 및 반응 $\mathrm{pH}$ 가 보다 다양한 것으로 알려져 있 다 $(20,21)$. 그러나 현재까지 젖산균의 $\beta$-xylosidase에 대한 연구는 국내외적으로 거의 보고되어 있지 않으며, 특히 Leuconostoc 속 의 경우 일본식 피클과 소의 분변에서 분리된 Leu. lactis를 이용 하여 가수분해된 자일란을 발효한 연구만이 보고된 정도이다(15).

본 연구에서는 전통 발효식품인 김치에서 분리된 Leuconostoc 속 젖산균의 $\beta$-xylosidase 활성을 탐색하여 높은 $\beta$-xylosidase 활 성을 갖는 균주를 선발하고자 하였다.

\section{재료 및 방법}

\section{균주}

한국식품연구원(Korea Food Research Institute, KFRI) 및 한국 생명공학연구원 미생물자원센터(Korean Collection for Type Cultures, $\mathrm{KCTC}$ )에 기탁되어 있는 배추김치를 비롯한 다양한 김치에 서 분리된 Leuconostoc 속 젖산균 55개 균주를 분양 받아 이들 균주의 $\beta$-xylosidase 활성을 탐색하였다.

\section{배양 조건}

균주는 $-80^{\circ} \mathrm{C}$ 에 보관하며 사용하였다. 보관된 균주를 탄소원 으로서 $20 \mathrm{~g} / \mathrm{L}$ 의 포도당이 첨가된 $5 \mathrm{~mL}$ 의 $\mathrm{MRS}$ (BD Diagnostic Systems, Sparks, MD, USA) 배지에 접종하고, 진탕배양기(Hanbaek Scientific Co., Bucheon, Korea)를 이용하여 $30^{\circ} \mathrm{C}$ 에서 10 시 간 동안 배양한 뒤, $600 \mathrm{~nm}$ 에서 흡광도 $\left(\mathrm{OD}_{600}\right)$ 를 측정하고 원심 분리하여 적정량의 세포를 회수하였다. 회수한 세포는 멸균 증류 수로 2회 세척한 후 자일로스(Sigma-Aldrich, St. Louis, MO, $\mathrm{USA}$ )를 비롯한 여러 가지 탄소원이 $20 \mathrm{~g} / \mathrm{L}$ 의 농도로 첨가된 MRS 배지에 초기 세포흡광도가 0.1 이 되도록 접종한 후, 진탕배양기 를 이용하여 흡광도가 1 이 될 때까지 $30^{\circ} \mathrm{C}$ 에서 배양하였고, 일 정량의 배양액을 회수한 뒤 원심분리하여 세포와 상등액을 분리 하였다.

배양시간에 따른 균체의 성장과 효소생산의 경향을 조사하기 위하여 탄소원으로 자일로스가 $30 \mathrm{~g} / \mathrm{L}$ 첨가된 $\mathrm{MRS}$ 배지 $100 \mathrm{~mL}$ 을 포함하고 있는 $500 \mathrm{~mL}$ 플라스크(Nalgene, Rochester, NY, USA)에 $20 \mathrm{~g} / \mathrm{L}$ 포도당이 포함된 MRS 배지에서 배양된 Leu. lactis $\mathrm{KCTC} 13344$ 균주를 멸균 증류수로 2회 세척한 후 초기 세포흡 광도가 0.1 이 되도록 접종하였다. 접종 후 36 시간 동안 배양하면 서 일정 시간마다 배양액을 회수한 뒤 균체농도 및 효소활성을 측정하였으며, HPLC(LC-20A Prominence, Shimadzu, Kyoto, Japan)를 이용하여 자일로스, 젖산, 아세트산 및 에탄올 농도를 측정하였다.

\section{HPLC 분석}

HPLC 분석을 위하여 사용한 컬럼은 Rezex ROA-Organic Acid $\mathrm{H}^{+}$(Phenomenex, Torrance, CA, USA)였으며, 이동상으로 $5 \mathrm{mM}$ $\mathrm{H}_{2} \mathrm{SO}_{4}$ 를 $0.6 \mathrm{~mL} / \mathrm{min}$ 의 유속으로 흘려주었다. 검출기는 굴절률 검 출기(Refractive Index Detector, Shimadzu)를 사용하였다.

\section{세포외 효소활성}

$\beta$-Xylosidase의 효소활성은 Lee 등(22)의 방법을 일부 수정하여 수행하였다. 세포가 제거된 상등액을 조효소액으로 이용하였고, $p$-nitrophenol 용액(Sigma-Aldrich)을 여러 농도로 희석한 뒤 $450 \mathrm{~nm}$ 에서의 흡광도를 측정하여 검량선을 작성하였다. 기질은 sodium phosphate 완충액 $(50 \mathrm{mM}, \mathrm{pH}$ 6)에 $p$-nitrophenyl- $\beta$-Dxylopyranoside(pNPX, Sigma-Aldrich)의 농도가 $5 \mathrm{mM}$ 이 되도록 용 해시킨 후, $70 \mu \mathrm{L}$ 의 조효소액에 기질용액을 $30 \mu \mathrm{L}$ 첨가하여 $37^{\circ} \mathrm{C}$ 에서 5 분 동안 반응시켰다. 효소반응은 $100 \mu \mathrm{L}$ 의 $0.5 \mathrm{M} \mathrm{Na}_{2} \mathrm{CO}_{3}$ (Duksan, Ansan, Korea)를 주입하여 종결하였다. 생성된 p-nitrophenol 농도는 $450 \mathrm{~nm}$ 에서 흡광도를 측정하고 미리 구한 검량선 을 이용하여 결정하였다. 1 unit의 효소활성은 $30^{\circ} \mathrm{C}, \mathrm{pH} 6$ 조건에 서 1 분 동안 $1 \mu \mathrm{mole}$ 의 $p$-nitrophenol을 생성하는 효소의 양으로 정의하였다. 모든 측정은 5 회 반복하였으며 결과의 평균값과 표 준오차는 SigmaPlot(ver. 11; Systat Software Inc., Chicago, IL, USA)을 이용하였고, 통계처리는 SPSS(ver. 18, SPSS Inc., Chicago, IL, USA)를 이용하여 분석하였다.

\section{세포내 효소활성}

배양액을 원심분리하여 얻은 세포에 sodium phosphate 완충액 (50 mM, pH 6) $700 \mu \mathrm{L}$ 와 $0.2 \mathrm{~mm}$ stainless bead(Nextadvance, Averill Park, NY, USA)를 $0.25 \mathrm{~g}$ 을 주입하고 균질기(Nextadvance) 를 이용하여 세포를 3 분 동안 파쇄하였다. 세포 파쇄물의 일정량 을 회수하고 원심분리 $\left(16,000 \times \mathrm{g}, 4^{\circ} \mathrm{C}, 15 \mathrm{~min}\right)$ 하여 조효소액을 얻 었다. 효소활성 측정 방법 및 정의는 세포외 효소활성 측정과 동 일하였다.

\section{단백질 정량}

Bradford Dye Reagent(Bio-Rad, Hercules, CA, USA)를 이용하 여 제조사가 제시한 조건에서 단백질 농도를 측정하였으며, 적정 농도로 희석된 bovine serum albumin(BSA, Bio-Rad)을 이용하여 검량선을 작성하였다.

\section{$\mathrm{pH}$ 및 온도에 대한 효소활성}

다양한 $\mathrm{pH}$ 의 완충액 $(\mathrm{pH}$ 3: sodium citrate $/ \mathrm{HCl}, \mathrm{pH}$ 4: sodium citrate/citric acid, $\mathrm{pH}$ 5: sodium acetate/acetic acid, $\mathrm{pH}$ 6, 7, 8: sodium phosphate, $\mathrm{pH}$ 9: Tris/ $\mathrm{HCl})$ 과 반응온도 $(20,30,37,40$, 50 및 $60^{\circ} \mathrm{C}$ ) 조건에서 효소활성을 측정하였다.

\section{금속이온에 대한 효소활성}

금속이온에 대한 $\beta$-xylosidase의 효소활성 변화를 조사하기 위 하여 효소반응 용액에 $\mathrm{CaCl}_{2}, \mathrm{CoCl}_{2}, \mathrm{CuCl}_{2}, \mathrm{FeCl}_{2}, \mathrm{MgCl}_{2}, \mathrm{MnCl}_{2}$ 및 $\mathrm{ZnCl}_{2}$ 의 최종 농도가 $2 \mathrm{mM}$ 이 되도록 첨가하여 효소활성을 측 정하였다.

\section{전기영동 및 활성염색}

Leu. lactis KCTC 13344 균주에서의 $\beta$-xylosidase 단백질 발현 경향을 조사하기 위하여 탄소원으로 포도당과 자일로스가 각각 
첨가된 MRS 배지에서 흡광도가 1까지 성장한 세포를 회수하였 다. Sodium dodecyl sulphate-polyacryamide gel electrophoresis(SDS-PAGE, $10 \%$ )는 Sambrook과 Russell의 방법(23)에 따라 수 행하였으며 단백질 염색은 Coomassie Brilliant Blue G-250(SigmaAldrich)을 이용하였다. $\beta$-Xylosidase의 활성염색은 Lee 등(22)의 방법을 변형하여 수행하였으며, SDS-PAGE 후 gel을 $50 \mathrm{mM}$ sodium phosphate $(\mathrm{pH}$ 6) 완충액으로 30 분간 2회 세척한 후 형광 기질인 $5 \mathrm{mM} p$-methylumbelliferyl- $\beta$-D-xylopyranoside( $\beta \mathrm{MUX})$ 와 $50 \mathrm{mM}$ sodium phosphate $(\mathrm{pH}$ 6)가 포함된 agarose gel $(0.8 \%, \mathrm{w} / \mathrm{v})$ 을 올려놓고 $30^{\circ} \mathrm{C}$ 에서 30 분 반응시킨 후 자외선 하에서 관찰하 였다.

\section{결과 및 고찰}

\section{김치에서 분리된 Leuconostoc 속 자일로스 대사}

젖산균을 배양하는데 주로 사용하는 MRS 배지에 함유된 포도 당을 자일로스로 대체하여 김치에서 분리된 Leuconostoc속 자일 로스 대사능을 조사하였다. 탄소원을 자일로스로 대체하여 젖산
균을 배양하였을 때, 실험에 사용한 55 개의 균주 중 36 개의 균 주는 자일로스를 탄소원으로 이용하였지만, Leu. inhae (KCTC 3774) 및 Leu. paramesenteroides(KFRI 88210) 등의 19개 균주는 자일로스를 탄소원으로 이용하지 못하였다. 배추김치, 총각김치, 깍두기, 파김치 등의 김치에서 분리되어 Leuconostoc 속 젖산균 으로 동정된 11 개의 균주 중 3 개 균주는 자일로스를 탄소원으로 이용하였지만, 나머지 8개 균주는 자일로스를 탄소원으로 이용하 지 못한 것으로 보고된 바 있다(24). 일본식 피클과 소의 분변에 서 각각 분리된 Leu. lactis SHO-47과 Leu. lactis SHO-54의 경우 포도당과 과당은 전혀 이용하지 못하였으며, 자일로스, 자일로바 이오스 및 자일로트리오스만을 탄소원으로 이용하였다(15).

\section{$\beta$-Xylosidase 효소활성}

배추김치를 비롯한 21 여 종류의 김치로부터 분리된 자일로스 를 탄소원으로 이용하는 36개의 Leuconostoc 속에 대하여 $\beta$ xylosidase 효소활성을 측정하였다. Fig. 1 에 표시된 것과 같이 실 험에 사용된 모든 균주에서 전반적으로 세포내 $\beta$-xylosidase 효소 활성과 세포외 활성이 비슷하였다. 가장 높은 세포내 $\beta$-xylosidase

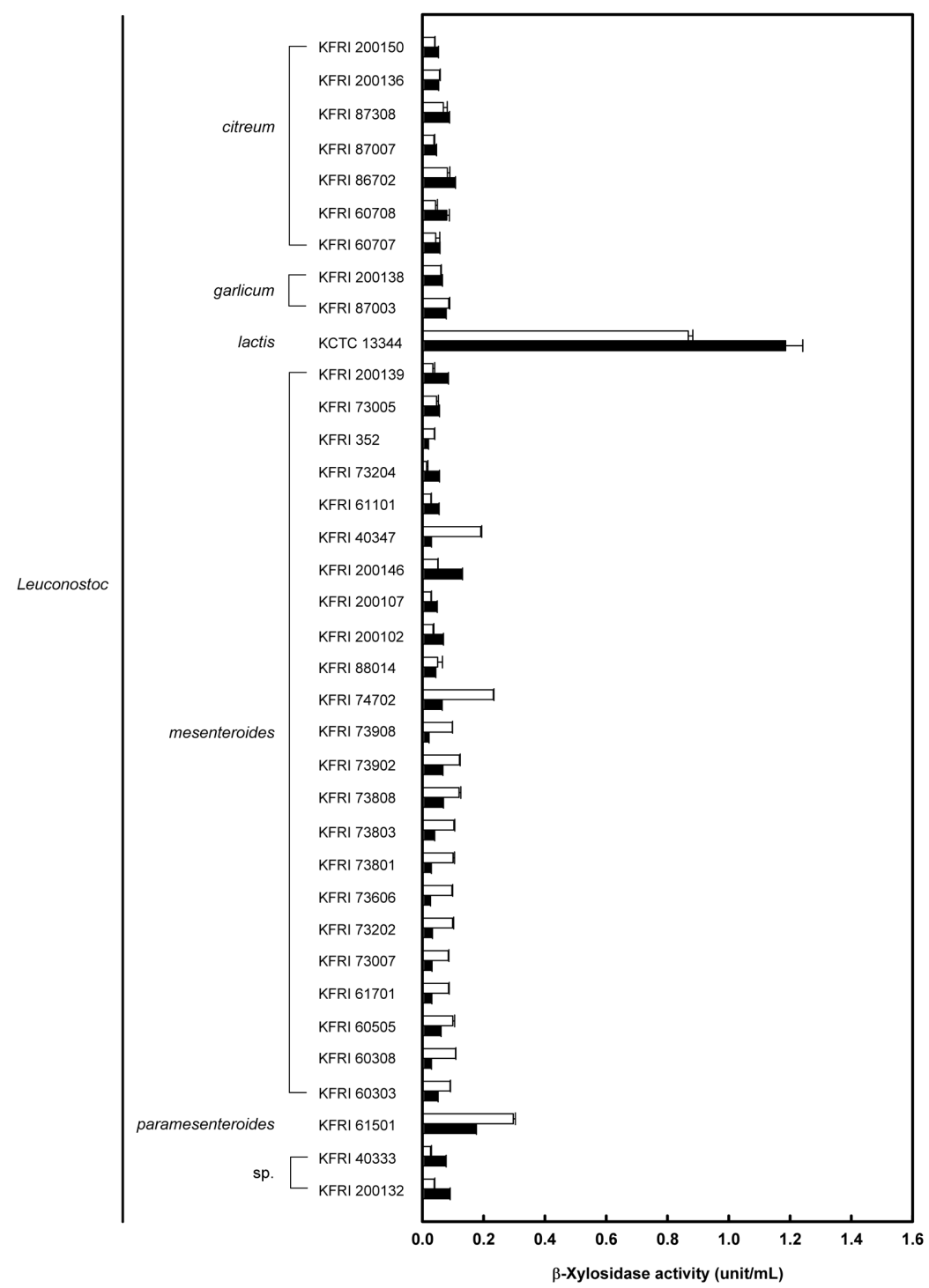

Fig. 1. $\beta$-Xylosidase activity of Leuconostoc sp. isolated from kimchi. Averages and standard errors from five independent experiments were determined and shown. Open $(\square)$ and closed $(\square)$ bars indicate extracellular- and intracellular $\beta$-xylosidase activity, respectively. 

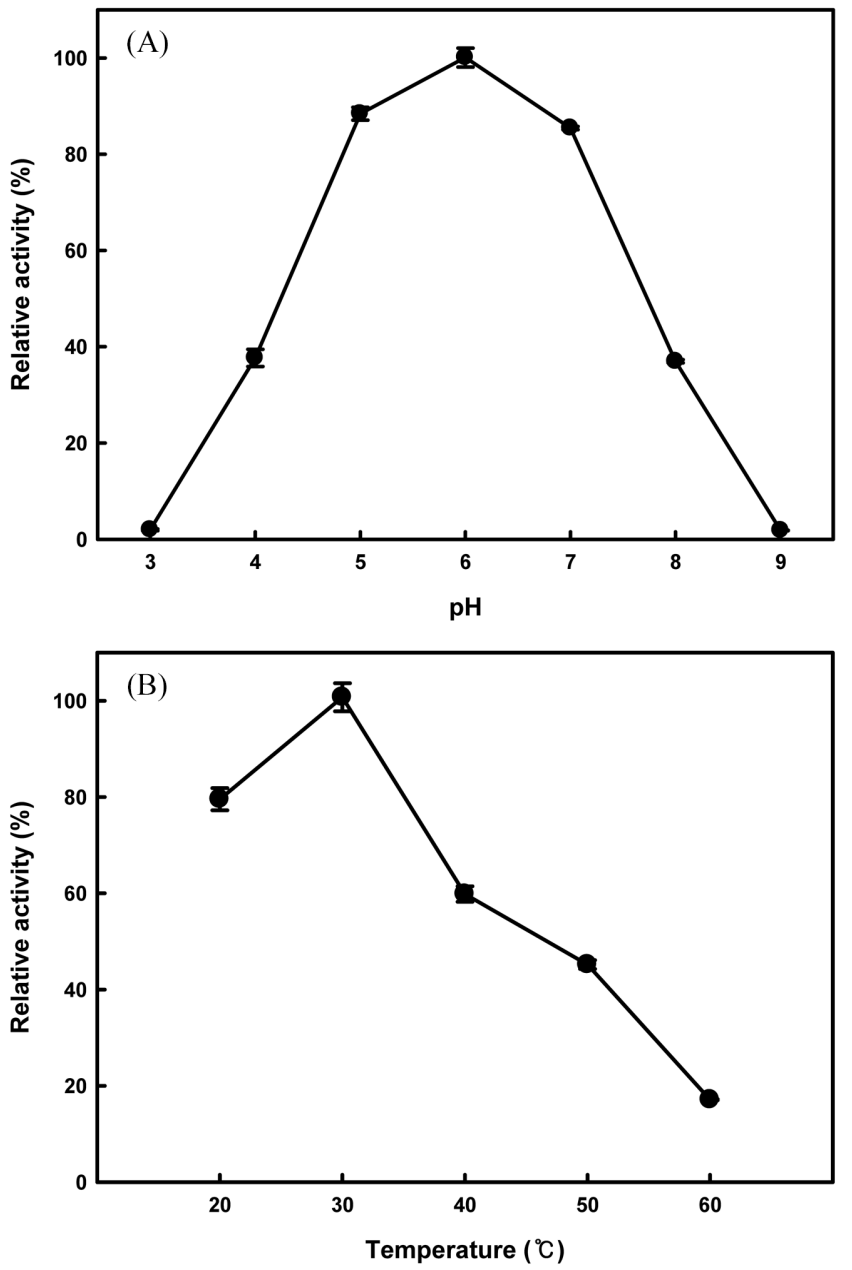

Fig. 2. Effect of pH (A) and temperature (B) on $\beta$-xylosidase activity of Leu. lactis KCTC 13344. Intracellular fraction was assayed for the enzyme activity. Averages and standard errors from five independent measurements were determined and shown.

효소활성을 나타낸 균주는 배추김치에서 분리된 Leu. lactis KCTC 13344 로서 $1.2 \pm 0.1$ units $/ \mathrm{mL}$ (평균 \pm 표준오차)이고, 가장 높은 세포 외 효소활성도 동일한 균주로서 $0.9 \pm 0.0 \mathrm{units} / \mathrm{mL}$ 이었다. $\beta$-Xylosidase가 주로 세포내에 존재하는 효소(16)임에도 불구하고 세포외 효소활성이 높은 균주는 Leu. mesenteroides KFRI 40347, KFRI 74702 및 Leu. paramesenteroides KFRI 61501로서 각각 0.2 \pm 0.0 , $0.2 \pm 0.0$ 및 $0.3 \pm 0.0$ units $/ \mathrm{mL}$ 을 나타내었다.

일본식 피클에서 분리된 Leu. lactis SHO-47은 $2.5 \mathrm{units} / \mathrm{mg}$ protein, 소의 분변에서 분리된 Leu. lactis SHO-54는 $2.1 \mathrm{units} / \mathrm{mg}$ protein의 $\beta$-xylosidase 효소활성을 나타내었다(15). 흙에서 분리된 Streptomyces sp. CH-M-1035의 $\beta$-xylosidase 효소활성은 1 units/ $\mathrm{mg}$ protein였으며(25), 퇴비(볏짚)로부터 분리된 Streptomyces $\mathrm{sp}$.는 탄소원이 자일로스일 경우 $\beta$-xylosidase 효소활성은 측정되지 않 았으나, 자일로바이오스의 경우 $280 \mathrm{units} / \mathrm{mg}$ protein의 $\beta$-xylosidase 효소활성이 보고된 바 있다(16). 세균의 경우 토양에서 분리된 호 열성균인 Paenibacillus sp. DG-22가 $2.5 \mathrm{units} / \mathrm{mg}$ protein의 $\beta$ xylosidase 효소활성을 나타내어 본 연구와 유사한 수준의 효소활 성을 나타냈으며(22), 그 외에 흙에서 분리된 호열성 B. stearothermophilus 는 34.2 units/mg protein(20), 부패한 풀에서 분리된 $C$. cellulolyticum은 0.09 units/mg protein의 효소활성을 나타내었다(21).
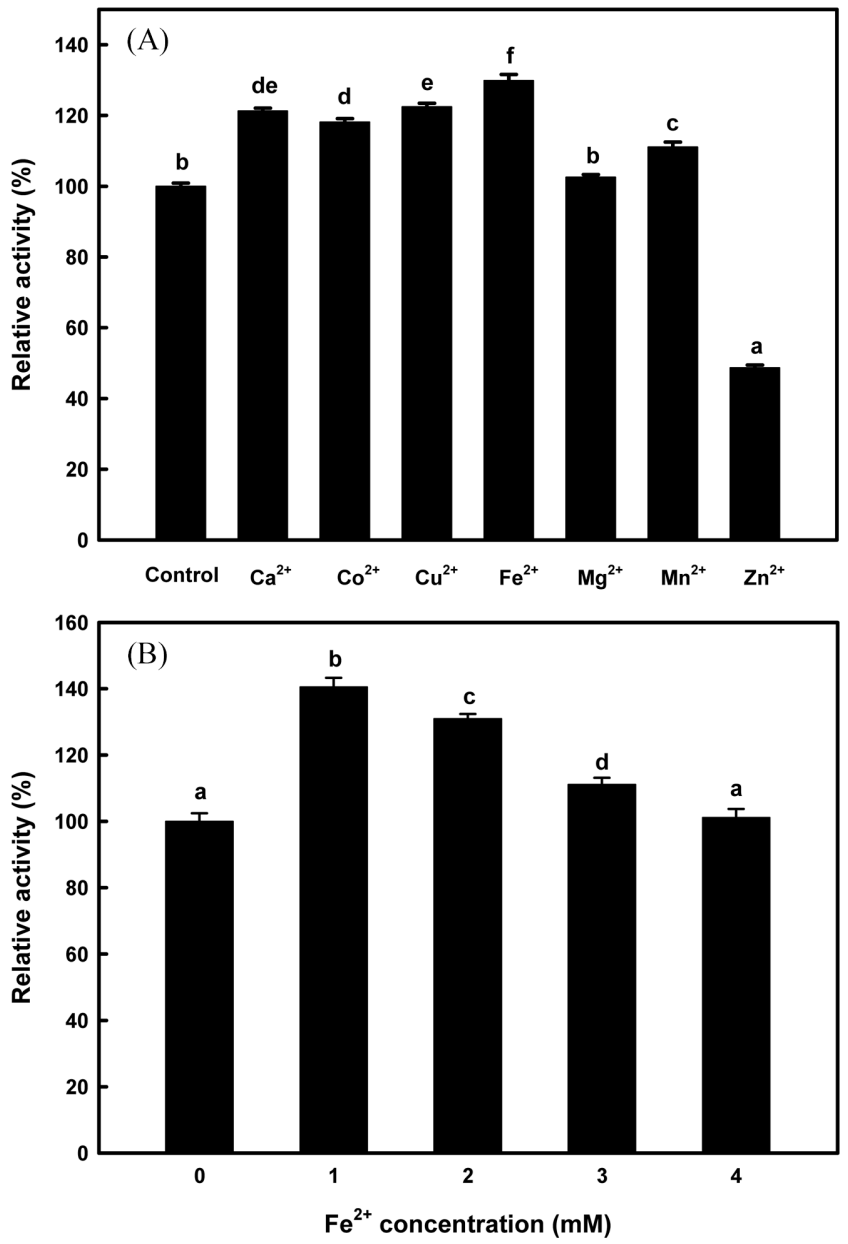

Fig. 3. Effect of divalent cations on $\beta$-xylosidase activity of $\mathbf{L e u}$. lactis KCTC 13344. In panel A, divalent cation was added to the reaction mixture at final concentration of $2 \mathrm{mM}$. Panel B shows the effect of various concentrations of $\mathrm{Fe}^{2+}$ on $\beta$-xylosidase activity. Averages and standard errors from five independent experiments were shown. Based on Duncan's Multiple Range Test $(p<0.05)$, different letter indicates significant difference between means.

곰팡이의 경우 훍에서 분리된 Fusarium verticillioides NRRL 26518 은 자일란을 탄소원으로 이용할 때 57 units $/ \mathrm{mg}$ protein의 $\beta$ xylosidase 효소활성을 나타내었다(19).

\section{반응 $\mathrm{pH}$ 및 온도에 대한 $\beta$-xylosidase 효소활성}

자일로스를 탄소원으로 대사할 수 있는 36 개의 젖산균 중 $\beta$ xylosidase 효소활성이 가장 높은 Leu. lactis KCTC 13344 균주를 이용하여 $\mathrm{pH}$ 와 온도에 대한 $\beta$-xylosidase의 효소활성 변화를 조 사하였다. 반응용액의 $\mathrm{pH}$ 에 대한 KCTC 13344 균주의 $\beta$-xylosidase의 활성은 $\mathrm{pH}$ 6에서 가장 높았으며, 염기성 조건과 산성 조 건에서 비슷한 활성을 나타내었다(Fig. 2A). 반응온도에 대한 $\mathrm{KCTC} 13344$ 균주의 $\beta$-xylosidase의 활성은 $30^{\circ} \mathrm{C}$ 에서 가장 높은 효소활성을 나타내었으며, 높은 반응온도 $\left(40,50,60^{\circ} \mathrm{C}\right)$ 보다는 낮 은 반응온도(20)에서 상대적으로 효소활성이 우수하였다(Fig. 2B).

Pseudomonas sp. CB-33은 $\mathrm{pH}$ 7의 sodium phosphate 완충액과 $45^{\circ} \mathrm{C}$ 에서 $\beta$-xylosidase 효소활성이 가장 높은 것으로 보고되었으 며(26), 곰팡이인 A. niger $\mathrm{KG} 79$ 는 $\mathrm{pH} 3.5$ 와 $65^{\circ} \mathrm{C}$ 에서 가장 높은 효소활성을 나타내었다(27). 식물 부패병의 원인균 중 하나인 $T$. 

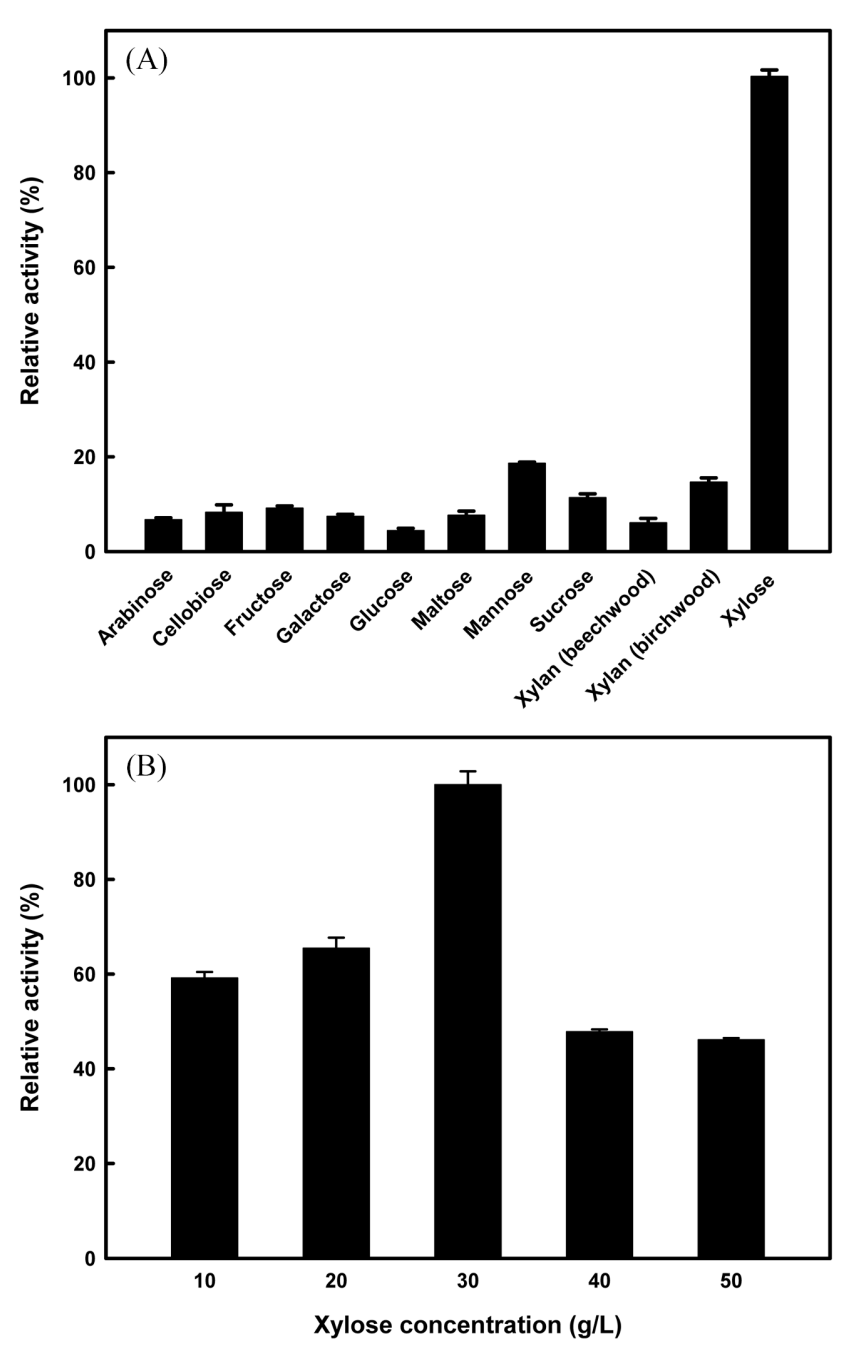

Fig. 4. Intracellular $\beta$-xylosidase activity of Leu. lactis KCTC 13344 grown in a variety of carbon sources. Each carbon source was added to MRS medium at a final concentration of $20 \mathrm{~g} / \mathrm{L}$ (panel A). Panel B shows the effect of xylose concentration on $\beta$-xylosidase activity. Averages and standard errors from five independent measurements were shown.

reesei의 경우 $\mathrm{pH} 2.5$ 에서 가장 높은 $\beta$-xylosidase 효소활성을 나 타냈으며(18), F. verticillioides NRRL 26518은 $\mathrm{pH} 4.5,65^{\circ} \mathrm{C}$ 에서 효소활성이 가장 높았다(19). 영아의 건강과 관계 있는 균주로 주 목되고 있는 균으로 한국인의 분변에서 분리한 Bifidobacterium sp. Int-57의 경우 $\mathrm{pH} 7,40^{\circ} \mathrm{C}$ 에서 가장 높은 효소활성을 나타냈

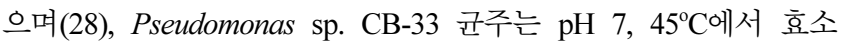
활성이 가장 높았다(26). B. stearothermophilus의 $\beta$-xylosidase는 최적 $\mathrm{pH}$ 가 본 균주와 유사하였으나, 최적온도는 $70^{\circ} \mathrm{C}$ 인 것으로 보고되었다(20).

\section{금속이온에 대한 $\beta$-xylosidase 효소활성}

금속이온에 대한 Leu. lactis KCTC 13344 균주의 $\beta$-xylosidase 효소활성을 조사하기 위하여 반응용액에 실험에 사용한 금속이 온들의 최종농도가 $2 \mathrm{mM}$ 이 되도록 첨가하여 효소활성을 측정하 였다. 효소활성을 측정한 결과, $\mathrm{Zn}^{2+}$ 을 제외하고 대부분의 금속이 온에 대해 유의적인 효소활성의 증가를 나타냈으며, 그 중 $\mathrm{Fe}^{2+}$ 을 첨가하였을 때 가장 높은 효소활성을 나타내었다(Fig. 3A).
$\mathrm{Fe}^{2+}$ 을 농도별 $(1,2,3,4 \mathrm{mM})$ 로 실험한 결과, $1 \mathrm{mM}$ 이 가장 높았 다(Fig. 3B).

$\mathrm{Hg}^{2+}, \mathrm{Cu}^{2+}$ 및 $\mathrm{Zn}^{2+}$ 는 Pseudomonas sp. CB-33의 $\beta$-xylosidase 효소활성을 완전히 저해하였고, $\mathrm{Mg}^{2+}, \mathrm{Na}^{+}, \mathrm{K}^{+}, \mathrm{Mn}^{2+}, \mathrm{Ca}^{2+}$ 및 $\mathrm{Li}^{2+}$ 는 효소활성을 유의적으로 증가시킨 것으로 보고되었다(26).

\section{탄소원에 대한 $\beta$-xylosidase 효소활성}

Leu. lactis KCTC 13344를 배양할 때 사용하는 탄소원이 세포 내 $\beta$-xylosidase 효소활성에 미치는 영향을 조사하였다(Fig. 4A). 자일로스를 제외한 모든 탄소원에서 $\beta$-xylosidase의 활성이 현저 히 감소하였다. 특히 포도당의 경우 대조구(자일로스)에 비해 20 배 이상의 낮은 효소활성을 나타냈으며, 그 밖에 자일란(beechwood)과 아라비노스도 $\beta$-xylosidase의 활성을 크게 저해시켰다. 효 소활성은 xylose를 첨가하였을 때 가장 높게 나타났으며, 자일로 스 농도에 대한 $\beta$-xylosidase의 활성을 조사한 결과, 자일로스 농 도가 $30 \mathrm{~g} / \mathrm{L}$ 인 경우에 가장 높은 효소활성을 나타내었다(Fig. 4B). 본 연구에 사용한 Leu. lactis KCTC 13344의 경우 문헌에 보고 된 Bifidobacterium sp. 균주와 유사하게 자일로스가 $\beta$-xylosidase 의 생산을 유도하는 것으로 추정되었다(28). 자일로스를 주성분 으로 하는 다당류인 자일란의 경우 탄소원으로 자일로스를 첨가 한 경우와 비슷한 수준의 효소활성을 얻을 것으로 예상하였으 나, 자일로스와 비교하여 현저하게 낮은 효소활성을 나타내었다. 이러한 결과로부터 $\beta$-xylosidase의 발현 유도는 세포내로 유입되 기 어려운 자일란보다 상대적으로 분자량이 작은 자일로스에 의 한 효과가 크다는 것을 의미하는 것이며, 본 연구에 사용된 균주 의 세포외 $\beta$-xylosidase 활성이 매우 낮다는 사실은 자일란에 의 한 $\beta$-xylosidase 발현 유도 효과가 크지 않다는 실험결과를 일부 증명하는 것으로 추정되었다. Paenibacillus sp. DG-22의 $\beta$-xylosidase는 셀로바이오스 및 자일란에 의해서 생산이 증가되었으며, 아라비노스, 갈락토스, 포도당 및 만노스와 같은 단당류에 의해 서는 생산이 유의적으로 억제되고, 자일로스의 경우 탄소원이 없 는 배지와 비슷한 효소활성이 나타나는 것으로 보고되었다(22). 그러나 Streptomyces sp. CH-M-1035는 자일란(larchwood, birchwood, oat spelt)과 같은 다당류에서 높은 $\beta$-xylosidase 효소활성을 나타내었다(25). Bifidobacterium sp. Int-57(28)과 T. reesei(18)는 본 균주와 유사하게 자일로스를 탄소원으로 이용하였을 경우 가 장 높은 효소활성을 나타냈다. Streptomyces sp. 균주는 자일로스 를 탄소원으로 이용하지 못하였으며, 글리세롤, 자일란 및 자일 로바이오스를 탄소원으로 이용하였을 때 높은 $\beta$-xylosidase 효소 활성을 나타내었다(16).

\section{단백질 전기영동 및 활성염색}

Leu. lactis KCTC 13344가 생산하는 $\beta$-xylosidase의 탄소원에 대한 발현경향 및 효소단백질의 분자량을 추정하기 위해 $20 \mathrm{~g} / \mathrm{L}$ 의 포도당과 $30 \mathrm{~g} / \mathrm{L}$ 의 자일로스가 각각 탄소원으로 첨가된 MRS 배지에서 배양된 세포로부터 얻은 단백질을 전기영동한 후 형광 기질인 $\beta \mathrm{MUX}$ 를 이용하여 활성염색을 실시하였다. 표준크기 단 백질과의 상대적인 이동거리(relative mobility, Rf)를 바탕으로 단 백질의 분자량을 추정한 결과 약 $64 \mathrm{kDa}$ 크기의 단백질이 자일 로스가 탄소원으로 사용된 실험구에서 발현되는 것을 확인할 수 있었다(Fig. 5). 따라서 Leu. lactis KCTC 13344에서 생산되는 $\beta$ xylosidase는 xylose에 의해 발현이 유도되며 분자량이 $64 \mathrm{kDa}$ 인 단백질이거나 동일한 $64 \mathrm{kDa}$ 크기의 소단위로 구성된 단백질일 것으로 추정되었다. 활성염색 결과 전체 단백질과 가용성 단백질 에서 $\beta$-xylosidase의 기질분해능이 나타나고, 불용성 단백질에서 


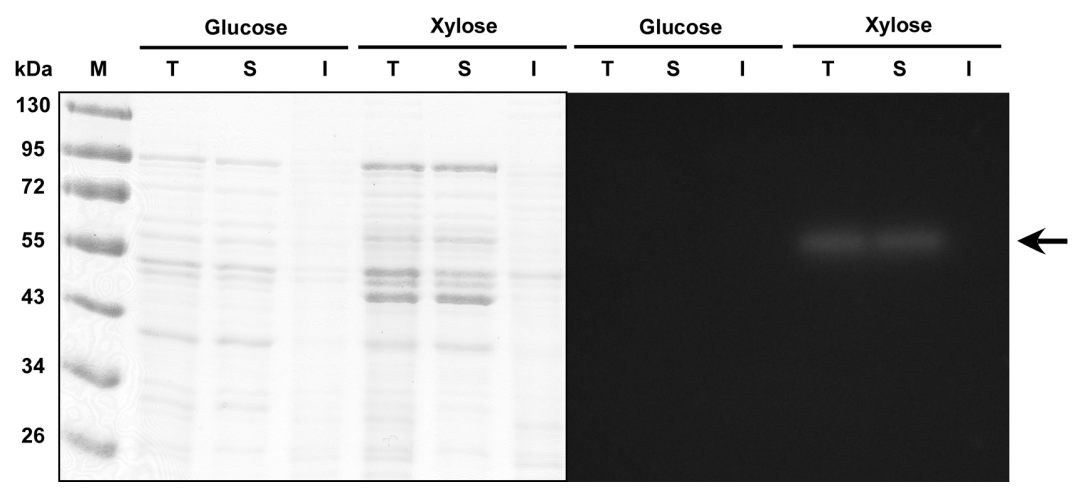

Fig. 5. SDS-PAGE (left panel) and zymographic analysis (right panel) of intracellular protein of Leu. lactis KCTC 13344. Lane M, molecular size markers; lane T, total fraction; lane S, soluble fraction; lane I, insoluble fraction. An arrow indicates the putative $\beta$-xylosidase.

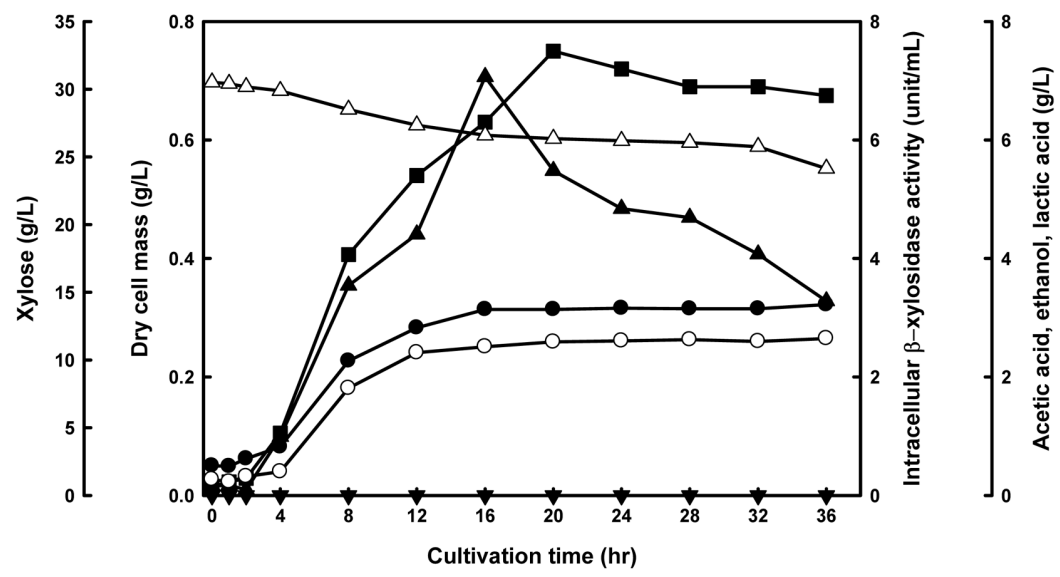

Fig. 6. Profiles of cell growth and intracellular $\beta$-xylosidase activity of Leu. lactis KCTC 13344 in MRS medium containing xylose as carbon source. $\bigcirc$, acetic acid; $\boldsymbol{\square}$, dry cell mass; $\boldsymbol{\nabla}$, ethanol; independent measurements were averaged and shown.

나타나지 않아 본 균주에서 발현되는 $\beta$-xylosidase는 가용성 단백 질인 것으로 판단되었다.

문헌에 보고된 Paenibacillus sp. DG-22의 경우는 $\beta \mathrm{MeXyl}$ 에 의 해 발현이 유도된 $\beta$-xylosidase가 $80 \mathrm{kDa}$ 크기의 단백질에서 활성 이 나타났으며(22), F. verticillioides NRRL 26518는 $94.5 \mathrm{kDa}$ 크 기의 $\beta$-xylosidase가 보고되었다(19). Pseudomonas sp. CB-33의 $\beta$-xylosidase 분자량은 $44 \mathrm{kDa}$ 이며(26), B. stearothermophilus 균주 의 $\beta$-xylosidase의 단백질 크기는 $150 \mathrm{kDa}$ 으로 $75 \mathrm{kDa}$ 의 두 개의 소단위 효소로 이루어진 것으로 보고되었다(20).

\section{배양시간에 따른 $\beta$-xylosidase 효소활성}

$\beta$-Xylosidase 효소활성이 가장 높은 $30 \mathrm{~g} / \mathrm{L}$ 의 자일로스를 사용 하여 Leu. lactis KCTC 13344를 배양하여, 배양시간에 따른 균체 성장, 효소 생산, 자일로스 소모량, 젖산, 아세트산 및 에탄올의 생성 경향을 조사하였다(Fig. 6). Leu. lactis KCTC 13344의 균체 성장은 접종 후 약 20 시간 후에 정지기에 도달하였으며, 배양초 기에 주입한 자일로스를 완전히 대사하지 못하고 시간이 경과할 수록 점차 감소하였다. 자일로스의 경우 $20 \%$ 의 소모량을 나타냈 고, 젖산과 아세트산은 약 $3.0 \mathrm{~g} / \mathrm{L}$ 수준으로 생성되었으나 에탄올 은 생성되지 않았다. 이러한 결과는 탄소원인 자일로스를 이용하 면서 생성된 젖산과 아세트산에 의하여 균체성장이 저해되기 때 문인 것으로 추정되었다(22,26). $\beta$-Xylosidase 효소활성은 배양 개 시 후 16 시간 후에 $7.1 \pm 0.3$ units $/ \mathrm{mL}$ 을 나타내었다. 문헌에 보고
된 Leu. lactis SHO-47과 SHO-54는 가수분해된 자일란을 이용하 여 약 $2.0 \mathrm{~g} / \mathrm{L}$ 수준의 젖산 및 아세트산을 생산하였다(15).

\section{요 약}

$\beta$-Xylosidase 효소활성이 높은 균주를 선발하기 위하여 다양한 김치에서 분리된 Leuconostoc 속 젖산균의 $\beta$-xylosidase 활성을 탐 색하였다. 김치에서 분리된 55개의 Leuconostoc 속 젖산균 중 36 개의 균주만이 자일로스를 탄소원으로 이용하였으며, 배추김치에 서 분리된 Leu. lactis KCTC 13344 균주가 가장 높은 세포내 $\beta$ xylosidase 효소활성을 나타내었으며, 효소활성은 $\mathrm{pH} 6,30^{\circ} \mathrm{C}$ 반 응조건에서 가장 높게 나타났다. $\mathrm{Zn}^{2+}$ 을 제외한 금속이온은 효소 활성을 유의적으로 증가시켰으며, $\mathrm{Fe}^{2+}$ 은 $1 \mathrm{mM}$ 의 농도에서 $\beta$ xylosidase 대조구와 비교하여 효소활성을 약 $40 \%$ 증가시켰다. 균 주를 배양할 때 사용한 탄소원 중 자일로스가 가장 높은 효소활 성을 나타내었고, 효소활성을 위한 최적의 자일로스 농도는 30 $\mathrm{g} / \mathrm{L}$ 였다. 단백질 전기영동 및 활성염색을 수행한 결과 분자량이 약 $64 \mathrm{kDa}$ 인 Leu. lactis KCTC 13344 균주의 $\beta$-xylosidase는 자 일로스에 의하여 발현이 유도되는 것으로 추정되었다. 자일로스 가 $30 \mathrm{~g} / \mathrm{L}$ 의 농도로 첨가된 $\mathrm{MRS}$ 배지에서 Leu. lactis KCTC 13344 균주의 성장은 20시간 후에 최고에 도달하였고, $\beta$-xylosidase 효소활성은 16 시간 후에 최대 $7.1 \pm 0.3$ units $/ \mathrm{mL}$ 이었다. 배양 초기 에 주입한 자일로스는 약 $20 \%$ 정도 소모하였고, 젖산과 아세트 
산은 $3.0 \mathrm{~g} / \mathrm{L}$ 수준으로 생성되었지만 에탄올은 생성되지 않았다.

\section{감사의 글}

본 연구는 지식경제부 지역산업기술개발사업(과제번호: 70011259), 지방기술혁신사업(RTI05-01-02)의 지원으로 수행되었습니다.

\section{문 헌}

1. Kim MJ, Kim GR. In vitro evaluation of cholesterol reduction by lactic acid bacteria extracted from kimchi. Korean J. Culin. Res. 12: 259-268 (2006)

2. Gill HS. Probiotics to enhance anti-infective defences in the gastrointestinal tract. Best Pract. Res. Cl. Ga. 17: 755-773 (2003)

3. Jayaprakasha HM, Yoon YC, Paik HD. Probiotic functional dairy foods and health claims: an overview. Food Sci. Biotechnol. 14: 523-528 (2005)

4. Saarela M, Lähteenmäki L, Crittenden R, Salminen S, MattilaSandholm T. Gut bacteria and health foods- the European perspective. Int. J. Food Microbiol. 78: 99-117 (2002)

5. Seo JH, Lee H. Characteristics and immunomodulating activity of lactic acid bacteria for the potential probiotics. Korean J. Food Sci. Technol. 39: 681-687 (2007)

6. Sunna A, Antranikian G. Xylanolytic enzymes from fungi and bacteria. Crit. Rev. Biotechnol. 17: 39-67 (1997)

7. Ernest K, Yu C, Deschatelets L, Saddler JN. The combined enzymatic hydrolysis and fermentation of hemicellulose to 2,3-butanediol. Appl. Microbiol. Biot. 19: 365-372 (1984).

8. Meyrial V, Delgenes JP, Moletta R, Navarro JM. Xylitol production from D-xylose by Candida guillermondii: fermentation behaviour. Biotechnol. Lett. 13: 281-286 (1991)

9. Song HS, Choi YJ. Production of xylanase by Bacillus stearothermophilus. Korean J. Appl. Microbiol. Bioeng. 17: 289-294 (1989)

10. Gong CS, Chen LF, Flickinger MC, Tsao GT. Conversion of hemicellulose carbohydrates. Adv. Biochem. Eng. Biotechnol. 20: 93-118 (1981)

11. Eliasson A, Hofmeyr JHS, Pedler S, Hahn-Hägerdal B. The xylose reductase/xylitol dehydrogenase/xylulokinase ratio affects product formation in recombinant xylose-utilising Saccharomyces cerevisiae. Enzyme Microb. Technol. 29: 288-297 (2001)

12. Martín C, Galbe M, Wahlbom CF, Hahn-Hägerdal B, Jönsson LJ. Ethanol production from enzymatic hydrolysates of sugarcane bagasse using recombinant xylose-utilising Saccharomyces cerevisiae. Enzyme Microb. Tech. 31: 274-282 (2002)

13. Dien BS, Hespell RB, Wyckoff HA, Bothast RJ. Fermentation of hexose and pentose sugars using a novel ethanologenic Escherichia coli strain. Enzyme Microb. Tech 23: 366-371 (1998)

14. Dien BS, Nichols NN, O'Bryan PJ, Bothast RJ. Development of new ethanologenic Escherichia coli strains for fermentation of lignocellulosic biomass. Appl. Biochem. Biotech. 84-86: 181-196 (2000)

15. Ohara H, Owaki M, Sonomoto K. Xylooligosaccharide fermentation with Leuconostoc lactis. J. Biosci. Bioeng. 101: 415-420 (2006)

16. Godden B, Legon T, Helvenstein P, Penninckx M. Regulation of the production of hemicelluloytic and cellulolytic enzymes by a Streptomyces sp. growing on lignocellulose. J. Gen. Microbiol. 135: 285-292 (1989)

17. Wong KKY, Saddler JN. Trichoderma xylanases, their properties and application. Crit. Rev. Biotechnol. 12:413-435 (1992)

18. Kristufek D, Zeilinger S, Kubicek CP. Regulation of $\beta$-xylosidase formation by xylose in Trichoderma reesei. Appl. Microbiol. Biot. 42: 713-717 (1995)

19. Saha BC. Hemicellulose bioconversion. J. Ind. Microbiol. Biot. 30: 279-291 (2003)

20. Nanmori T, Watanabe T, Shinke R, Kohno A, Kawamura Y. Purification and properties of thermostable xylanase and $\beta$-xylosidase produced by a newly isolated Bacillus stearothermophilus strain. J. Bacteriol. 172: 6669-6672 (1990)

21. Saxena S, Fierobe HP, Gaudin C, Guerlesquin F, Belaich JP. Biochemical properties of a $\beta$-xylosidase from Clostridium cellulolyticum. Appl. Environ. Microb. 61: 3509-3512 (1995)

22. Lee TH, Lim PO, Lee YE. Regulation of $\beta$-xylosidase biosynthesis in Paenibacillus sp. DG-22. J. Life Sci. 17: 407-411 (2007)

23. Sambrook J, Russell DW. Molecular Cloning a Laboratory Manual. Vol. 3. Cold Spring Harbor Laboratory Press. New York. NY. USA. pp. A 8.40-A 8.51 (2001)

24. Ko JL, Oh CK, Oh MC, Kim SH. Isolation and Identification of lactic acid bacteria from commercial kimchi. J. Korean Soc. Food Sci. Nutr. 38: 732-741 (2009)

25. Flores ME, Perea M, Rodríguez O, Malváez A, Huitrón C. Physiological studies on induction and catabolite repression of $\beta$ xylosidase and endoxylanase in Streptomyces sp. CH-M-1035. J. Biotechnol. 49: 179-187 (1996)

26. Yu JW, Kim HK, Kim CK, Lim JY. Characterization of $\beta$-xylosidase from Pseudomonas sp. CB-33. Korean J. Appl. Microbiol. Biotechnol. 24: 197-205 (1996)

27. Lee HJ, Choi YD, Han MH. Studies of hemicellulase system in Aspergillus niger-purification and characterization of $\beta$-xylosidase. Korean J. Appl. Microbiol. Biotechnol. 11: 93-100 (1983)

28. Kang DH, Lee KH, Ji GE. Production of $\beta$-xylosidase from Bifidobacterium sp. Int-57. Korean J. Food Sci. Technol. 25: 89-93 (1993) 